\title{
State development institutions as the basis of the developed institutional environment of the national agro-industrial complex
}

\author{
O. A. Rushchitskaya ${ }^{1}$, A. O. Zagurskiy ${ }^{1}$ \\ ${ }^{1}$ Ural State Agrarian University, Ekaterinburg, Russia \\ ${ }^{\otimes}$ E-mail: Zagurskiy-ao@yandex.ru
}

Abstract. The purpose of this article is to study the problems of identification of state development institutions in the agricultural and industrial complex, as an element of the institutional environment, as an integral part of the system of development of the national economy through state regulation of strategic development processes in the agroindustrial complex. Methods of abstraction, analysis and synthesis were used in the course of the study. Results and practical significance. The author's research of the state regulation of the development of the national agro-industrial complex is presented in the context of the study of state programs as a form of state development institution that ensures the effective functioning of the institutional environment. The scientific novelty of the research is presented by the author's non-standard approach to the identification of state development institutions in the agro-industrial complex, the author's vision of the structure of the institutional environment for the development of the agro-industrial complex is presented, based on traditional approaches of institutionalism, two main systems of the development of the agro-industrial complex are derived, formed by the institutional environment, which in interaction form a system of strategic regulation of the national agro-industrial complex.

Keywords: state development institutions in the agricultural and industrial complex, institutional environment, state regulation of agriculture, strategic regulation, state programs, development system.

For citation: Rushchitskaya O. A., Zagurskiy A. O. State development institutions as the basis of the developed institutional environment of the national agro-industrial complex // Agrarian Bulletin of the Urals. 2021. No. 12 (215). Pp. 98-102. DOI: 10.32417/1997-4868-2021-215-12-87-97. (In Russian.)

Date of paper submission: 25.10.2021, date of review: 05.11.2021, date of acceptance: 11.11.2021.

\section{Introduction}

The problem of solving the issue of the development of such an important structure of the national economy as the agro-industrial complex, without taking into account such a scientific category as the "institutional environment" is not possible. The importance of this scientific category as an "institutional environment" is explained by the fact that the development of the state and regions is conditioned by active processes of institutional transformation and changes. From the standpoint of institutional economics, the institutional environment is characterized by a whole set of categories such as norms, rules, procedures, sets of unwritten rules [1, p. 7]. From the point of view of economic and economic relations, the institutional environment is a system of legislatively approved and informal rules that affect production and exchange processes, which affects the efficiency of the functioning of economic entities [6, p. 81].

From the point of view of state regulation, the institutional environment is a set of formalized tools and mechanisms in which an economic entity carries out its activities.
The formation of an effective system of state regulation of agriculture is directly related to the development of certain institutional mechanisms $[9$, p. 50]. Moreover, the increase in this efficiency is associated with an increase in competitiveness due to the implementation of a system of measures to consistently improve efficiency within the framework of a unified strategy for the development of the agro-food system [10, p. 640].

The state, exercising regulatory functions, is at the highest level of constitutional rules, being the basis of the political, legal and economic system, defines universal rules [7, p. 103].

The state, realizing its tasks of regulating the agroindustrial complex, provides the necessary support in ensuring the competitiveness of the products of the national manufacturer and, as a result, to import substitution [14, p. 33].

By influencing individual instruments and mechanisms of the institutional environment, the state thereby performs its functions as the main regulator of socioeconomic processes, thereby exerting a stimulating effect $[15$, p. 8$]$. 


\section{Agrarian Bulletin of the Urals No. 12 (215), 2021}

The built effective institutional environment forms individual incentives for economic entities, contributes to the formation of their resource base and modernization of production, increases the efficiency of their interaction processes with each other.

Nevertheless, despite the significant efforts of the state to form a favorable institutional environment, modern development conditions are characterized by a high level of uncertainty of the institutional environment [3, p. 134]

\section{Methods}

Methods of abstraction, analysis and synthesis were used in the course of the study. The author presents the structure of the institutional environment for the development of the agricultural and industrial complex, identifies the role of institutions and the development systems formed by them, which, in interaction with each other, form an integral system of strategic regulation. The author's position on the identification of state development institutions in the agricultural and industrial complex as the main component of the institutional environment is presented. In the study of the institutional environment in the agro-industrial complex, the author relies on the traditional approaches of institutionalism formed by D. North [17].

\section{Results}

Studying the issue of tools and mechanisms of the institutional environment in the process of state regulation of the agro-industrial complex (hereinafter referred to as the AIC), it is necessary to understand the structure of the relevant institutional environment. The structure of the institutional environment of the agro-industrial complex includes both formal and informal institutions that form two development systems: regulatory and directive and evolutionary. The structure of the institutional environment in the author's view is shown in Fig. 1.

In relation to this study, we consider the institutional structure in the agro-industrial complex as accepted norms and rules formed under the influence of state regulation and public interaction.

To understand the regulatory impact of state institutions, it is necessary to take into account the influence of the environment in which economic entities are immersed [5, p. 117].

The evolutionary system of development is formed under the influence of the objectively existing external environment, the level of development of society, the "rules of the game" formed in society. It is characterized by sufficient stability and not variability relative to the historical period.

The evolutionary system of development is formed under the influence of the interaction of such institutions as business customs, traditions, restrictions accepted in society.

The regulatory and directive system of development is formed under the influence of formal, state institutions. This development system is formed under the influence of the processes of state regulation of the AIC. Regulatory legal acts and development programs issued by state institutions in the process of regulating the economy form the appropriate levers through which the state exercises its regulatory functions in relation to the AIC.

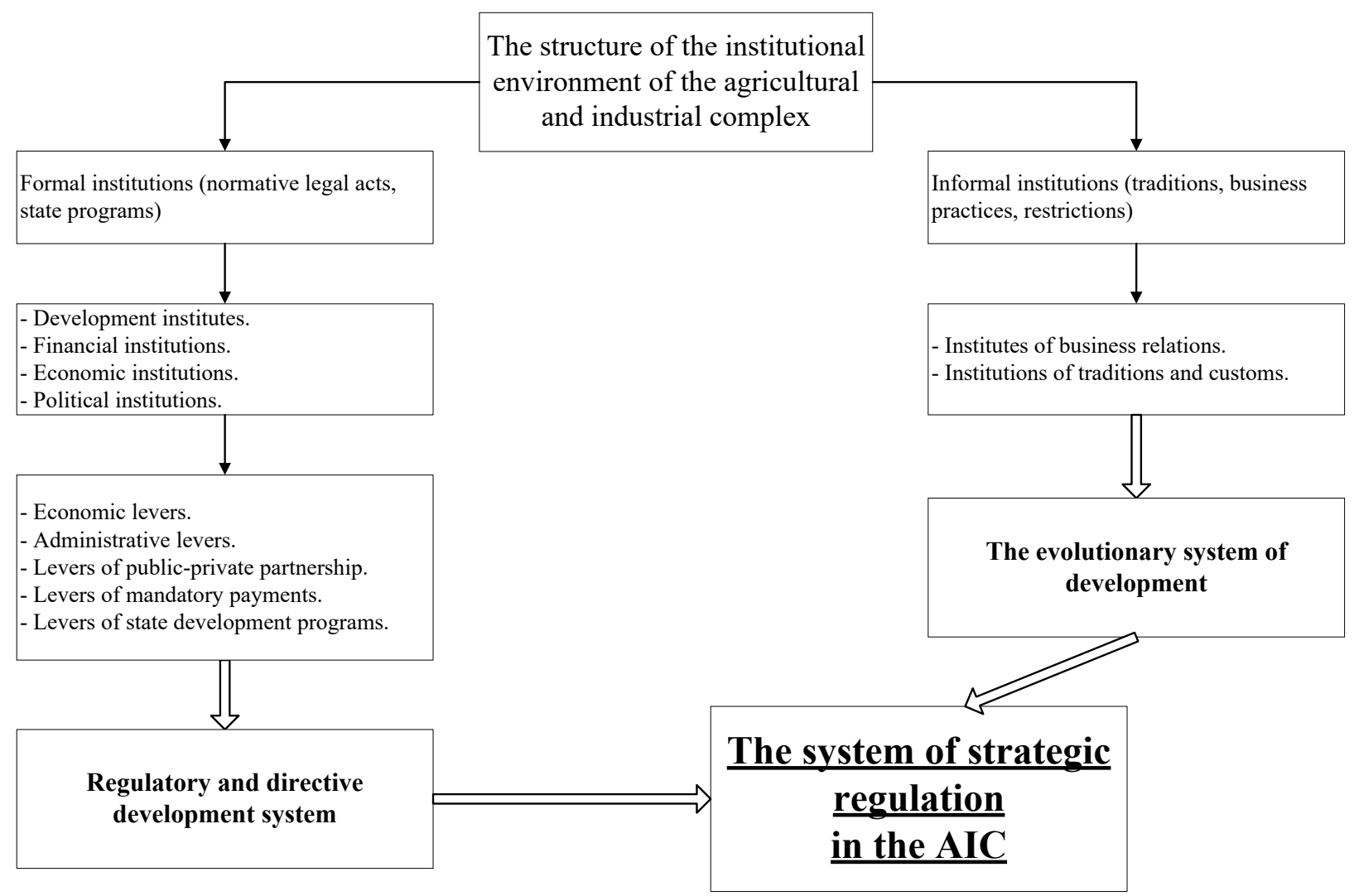

Fig. 1. Structure of the institutional environment of the Agro-Industrial Complex 
The presence of regulatory levers is the main distinguishing feature of the regulatory and directive system of development from the evolutionary one.

The presence of appropriate regulatory levers gives state institutions a special status, which can be described as a system of state institutional regulation of AIC.

The interaction of the two development systems (as an initial hypothesis of this interaction, we use the Helmke - Levitsky typology) form an integral system of strategic regulation. In the system of strategic regulation, the leading and dominant role is played by the regulatory and directive regulatory system, that is, state institutions. The evolutionary system of development and its bearer informal institutions form an external (basic) environment in which the levers of formal institutions are used.

In the system of strategic regulation of the development of agricultural industries, the most important place is occupied by state development institutions. From the point of view of regulatory impact on economic processes, state development institutions (hereinafter referred to as SDI) represent state development programs, extraprogrammatic activities.

Modern authors note that the main mechanisms of state regulation of priority areas of the AIC are implemented within the framework of sectoral state programs [12, p. 110].

A number of authors, describing the paradigm of SDI functioning, distinguish the following characteristic features of SDI [2, p. 231]:

1) SDI act within the framework of the strategic planning measures taken, defined by regulatory legal acts that are aimed at solving tasks to achieve strategic development goals;

2) SDI are subordinate to executive authorities (federal, regional, local) and represent an instrumental expression of their powers exercised by these bodies;

3) the management of the SDI is carried out by collegial management bodies exercising the authority to allocate funds and relevant mandates;

4) SDI are designed to solve a relatively limited range of tasks and are poorly coordinated among themselves.

In the scientific and professional environment, development institutions are commonly understood as organizations and institutions subordinate to government authorities, international organizations, and public associations. With regard to the agro-industrial complex, such organizations and institutions can be attributed to the Peasant Land Bank established in 1882 and operating until 1917. The modern ones include such organizations as Rosagroleasing Joint Stock Company, regional centers of competence in the field of agricultural cooperation and support for farmers.

However, from the perspective of strategic state regulation in the institutional environment, we take a different approach to the classification of development institutions, including SDI.

In our understanding, the SDI has a broader scope for understanding and represents the policy directions estab- lished and implemented by the state to achieve the set goals. Such institutions include state programs for the development of AIC.

At the same time, the role of state organizations and institutions should be reduced to the functions of an institutional agent for the implementation of the tasks of state development programs.

Thus, the institutional environment of state regulation of agriculture is the interaction of state development institutions and institutional agents.

As an example of such interaction, Table 1 presents state institutions for the development of AIC and institutional agents interacting with it, as well as objects of their influence.

As can be seen from Table 1, SDI in the AIC can be divided into different levels and categories, depending on the scale and objects of their impact. The complexity and dynamism of their structure forms the SDI system in AIC, as an integral part of the strategic development system in the agro-industrial complex.

The interaction of SDI and institutional agents is defined by some authors as the relationship between institutional participants in the process, the basis of the mechanism of which is the relationship based on the principle of systemic vision [4, p. 69].

The structure of the SDI system in the AIC depends on the center of the development initiative. Thus, in the State Program for the Development of Agriculture and Regulation of Agricultural Products, Raw Materials and Food Markets, the federal authorities are the center of the initiative, but the implementation of this program is transferred to regional and local levels through the implementation of relevant programs at the regional and local levels.

As an example of such a form of organization, we can cite the SME support program implemented by the Ministry of Economic Development of Russia jointly with the state authorities of the regions, which is distinguished by the multi-channel system of financial support for SME $[8$, p. 3].

Another example of such a form of organization is the regional project "Creating support for farmers and entrepreneurship in the Sverdlovsk region" developed by the Ministry of Agriculture and Consumer Market of the Sverdlovsk region, which includes activities similar to the federal project of the same name. This project is a direct component of the state program "Development of the agro-industrial complex and consumer market of the Sverdlovsk region until 2024" [11, p. 76].

National projects in the AIC represent a project form of state regulation of the development processes of the industry, both at the micro and macro levels [16, p. 75].

The effectiveness of state programs and, as a consequence, the SDI system in the AIC largely depends on the consistency of the directions and measures of state regulation with the priorities of strategic development $[13$, p. 52].

Institutional agents, as well as SDI, are divided into levels and categories. So, depending on the center of the 


\section{Agrarian Bulletin of the Urals No. 12 (215), 2021}

SDI initiative, institutional agents can be both at the federal level (federal executive authorities, federal services, state corporations of the federal level, etc.) and at the regional and local levels (regional executive authorities, municipal authorities, regional and municipal services, etc.).

The objects of the impact of SDI in the AIC are quite wide and heterogeneous areas to which the process of interaction between SDI and institutional agents is directed. The objects of influence can be economic processes in the AIC (agricultural production in general, investment processes and their activity in AIC, procedures for exporting agricultural products of a national manufacturer), individual segments and categories of producers (representatives of SME in the AIC, small forms of management), processes of technological development and improvement of the quality of products, rural areas.

Thus, the institutional environment for the development of the national AIC is largely formed due to the interaction of a dynamic and multi-level SDI system in the AIC aimed at solving development problems.

\section{Discussion and Conclusion}

The institutional environment for the development of the AIC is a relatively traditional structure consisting of formal and informal institutions. Informal institutions, as the most stable structure, form the conditions that ensure the process of evolutionary development of the national AIC, thereby forming a system of evolutionary development.

In the course of the study, we adhere to the position of scientists G. Helmke and S. Levitsky that informal institutions are characterized by high resistance to change and have such a quality as a high level of stability, including in relation to formal institutions [18, p. 204].

At the same time, scientists note that formal institutions are an important source of changes in informal institutions, serving as an important catalyst for institutional change.

We support this thesis, but with the clarification that the speed of informal institutional changes will depend on the role and nature of formal institutions in relation to informal institutions (whether they have a positive or negative impact)

The most important for the process of strategic development of the AIC are formal institutions in the person of its main element, the state, which forms and ensures the functioning of the regulatory and directive system for the development of the AIC. The state, in the process of regulating the AIC, forms its own institutional environment by ensuring the work of the SDI in the AIC.

From the perspective of the development of the national AIC, SDI should be understood not as individual organizations and institutions implementing state regulatory policy, but as integral and multilevel state development programs and corresponding subprogram complexes.

SDI provide an appropriate environment for the development of the national AIC, form a strategic level of development regulation, and ensure the long-term nature of the policy pursued by the state.

Ensuring the functioning of the institutional environment formed by the state is entrusted to institutional agents in the person of state authorities, institutions and organizations. These institutional agents implement individual mechanisms of the institutional environment or their integral complex to achieve the goals set by the SDI in the AIC.

The process of implementing regulatory mechanisms takes place through the interaction of SDI in the AIC and institutional agents, which is aimed at the relevant objects of influence in the face of a fairly wide list of categories related to the processes of economic relations in the AIC.

Thus, the results of the study demonstrate that the system of development of the agro-industrial complex consists of two parts: evolutionary and regulatory-directive. The interaction of these systems forms a common system of strategic regulation. In the implementation of regulatory functions by the state, it is important to accurately separate development institutions and their institutional agents, whose interaction forms the process of state regulation of the agro-industrial complex.

\section{References}

1. Borovskaya L. V. Institutsional'naya sreda i osobennosti ee formirovaniya v rezul'tate institutsional'nykh izmeneniy [Institutional environment and features of its formation as a result of institutional changes] // Proceedingsof the Voronezh State University. Series: Economics and Management. 2018. No. 4. Pp. 5-12. (In Russian.)

2. Petrov A. N., Varlamov K. V., Komarov A. V., Matveev D. A. Effektivnost' institutov razvitiya. Smena paradigmy institutov razvitiya $\mathrm{v}$ srednesrochnoy perspektive [The effectiveness of development institutions. Paradigm shift of development institutions in the medium term] // The Economics of Science. 2017. Vol. 3. No. 4. Pp. 230-239. DOI: 10.22394/2410-132X-2017-3-4-230-239. (In Russian.)

3. Solodilova N. Z. Institutsional'naya konfiguratsiya regional'noy delovoy sredy [Institutional configuration of the regional business environment] // Economic policy. 2017. Vol. 12. No. 3. Pp. 134-149. DOI: 10.18288/1994-51242017-3-05. (In Russian.)

4. Goykher O. L., Danilov A. I. Sistema vzaimootnosheniy mezhdu institutsional'nymi uchastnikami investitsionnogo protsessa $\mathrm{v}$ regione [The system of relations between institutional participants of the investment process in the region] // Vestnik Universiteta. 2016. No. 3. Pp. 69-72. (In Russian.)

5. Antonova N. E. Otsenka otklikov ekonomicheskikh agentov na institutsional'nye izmeneniya v lesnom komplekse regiona [Assessment of responses of economic agents to institutional changes in the forest complex of the region] // Spatial economics. 2018. No. 4. Pp. 115-138. DOI: 10.14530/se.2018.4.115-138. (In Russian.) 
6. Kokovikhin A. Yu., Ogorodnikova E. S., Uil'yams D., Plakhin A. E. Faktory institutsional'noy sredy v otsenke predprinimatelem investitsionnogo klimata munitsipal'nogo obrazovaniya [Factors of the institutional environment in an entrepreneur's assessment of the investment climate of a municipality] // Economy of regions. 2017. Vol. 13. No. 1. Pp. 80-92. DOI: 10.17059/2017-1-8. (In Russian.)

7. Pyzhev I. S., Goryachev V. P., Pyzhev I. S., Realizatsiya teoreticheskogo podkhoda k otsenke ekonomicheskoy effektivnosti institutsional'nykh izmeneniy na otraslevom rynke [Implementation of a theoretical approach to assessing the economic efficiency of institutional changes in the industry market] // Terra Economicus. 2018. Vol. 16. No. 2. Pp. 99-113. DOI: 10.23683/2073-6606-2018-16-2-99-113. (In Russian.)

8. Rushchitskaya O. A., Kulikova E. S. Razvitie malogo i srednego biznesa: mirovoy opyt i problemy Rossii [Development of small and medium-sized businesses: world experience and problems of Russia] // Agricultural education and science. 2016. No. 4. P. 7. (In Russian.)

9. Zyryanova T. V., Zagurskiy A. O. Institutsional'nye mekhanizmy gosudarstvennogo nalogovogo regulirovaniya sel'skogo khozyaystva [Institutional mechanisms of state tax regulation of agriculture] // Discussion. 2019. No. 6 (97). Pp. 48-54. DOI: 10.24411/2077-7639-2019-10047. (In Russian.)

10. Dudnik A. V., Cherdakova T. A., Dudnik A. V. Investitsionnye strategii povysheniya konkurentosposobnosti agroprodovol'stvennoy sistemy strany [Investment strategies to increase the competitiveness of the country's agrifood system] // Economy of regions. 2021. Vol. 17. Iss. 2. Pp. 632-643. DOI: 10.17059/ekon.reg.2021-2-20. (In Russian.)

11. Latypov R. T., Maleykina G. P., Ruchkin A. V., Latypov R. T. Grantovaya podderzhka realizatsii gosudarstvennykh programm i proektov po razvitiyu krest'yanskikh (fermerskikh) khozyaystv: opyt regiona i klyuchevye problemy [Grant support for the implementation of state programs and projects for the development of peasant (farm) farms: the experience of the region and key problems] // Agrarian Bulletin of the Urals. 2019. No. 8 (187). Pp. 75-90. DOI: 10.32417/article_5d908ec8145d33.94927172. (In Russian.)

12. Latypov R. T., Maleykina G. P., Ruchkin A. V. Effektivnost' podderzhki krest'yanskikh (fermerskikh) khozyaystv $\mathrm{v}$ regione [Effectiveness of support for peasant (farmer) farms in the region] // Bulletin NSUEE. 2019. No. 9 (100). Pp. 109-118. (In Russian.)

13. Mokrushin A. A. Programmno-tselevye instrumenty gosudarstvennogo regulirovaniya APK problemnogo regiona [Program-targeted tools of state regulation of the agro-industrial complex of the problem region] // Bulletin of the Adygea State University. Series 5: Economics. 2017. No. 3 (205). Pp. 43-53. (In Russian.)

14. Danilov N. A. Formirovanie i razvitie APK Sverdlovskoy oblasti [Formation and development of agroindustrial complex of Sverdlovsk region] // Problems of modern science and education. 2017. No. 29 (111). Pp. 31-35. (In Russian.)

15. Zyryanova T. V., Zagurskiy A. O., Zyryanov S. B. Gosudarstvennoe regulirovanie nalogovoy politiki v sel'skom khozyaystve na sovremennom etape: Ural'skiy gosudarstvennyy agrarnyy universitet [State regulation of tax policy in agriculture at the present stage: Ural State Agrarian University]. Ekaterinburg, 2020. 120 p. (In Russian.)

16. Zagurskiy A. O. Gosudarstvennoe regulirovanie APK v kontekste realizatsii strategicheskikh zadach razvitiya Rossii v chasti eksportnogo potentsiala [State regulation of the agro-industrial complex in the context of the implementation of strategic objectives of Russia's development in terms of export potential] // Agrarian Bulletin of the Urals. 2021. No. 3 (206). Pp. 74-80. DOI: 10.32417/1997-4868-2021-206-03-74-80. (In Russian.)

17. Nort D. Instituty, institutsional'nye izmeneniya i funktsionirovanie ekonomiki [Institutions, institutional changes and the functioning of the economy]. Moscow: Fond ekonomicheskoy knigi "Nachala", 1997. 180 p. (In Russian.)

18. Khelmke G., Levitski S. Neformal'nye instituty i sravnitel'naya politika [Informal institutions and comparative politics] // Magazine about the future. 2007. No. 2 (10). Pp. 188-211.

\section{Authors' information:}

Olga A. Ruschitskaya ${ }^{1}$, doctor of economic sciences, director of the institute of economics, finance and management, ORCID 0000-0002-6854-5723, AuthorID 518696; olgaru-arbitr@mail.ru

Aleksandr O. Zagurskiy ${ }^{1}$, lecturer of the department of accounting and audit, ORCID 0000-0002-0335-5806,

AuthorID 992052; Zagurskiy-ao@yandex.ru

${ }^{1}$ Ural State Agrarian University, Ekaterinburg, Russia 